\title{
Functions of 'Madrasas' in the Ottoman Period
}

\author{
Ayla Akbash \\ Kocaeli University,Turkey
}

\section{Introduction}

The understanding and practices of education of Turks during the times before they chose the religion of Islam were shaped with their own life style. The application of praying and worshipping and education based on the structure of the Turkish foundations may be considered to be the start of the process of formal and organized education. As a result of the sympathy for science which is observed during this era, some literary work was seen which had teaching and instructive effect on the society. These were based on such values as ethics, manners, goodness, generosity, wisdom, braveness, respect for the old people which were the social values of the Turkish society during these eras. The secondary goal of education was bringing up heroic type individuals.

\section{The Factors Which Necessitated the Madras as}

The Islamic world used mosques and small mosques at the beginning as means for giving religious education. However, due to the fact that such structures are places for praying and worshipping, the need for finding new places for education arose as a result of the facts that the religious education spoilt the peace and quietness, that the understanding of cleanness disappeared, that the number of students were increasing over time, that it became impossible to worship timely and decently in such places, and that there was not a convenient atmosphere in these buildings for education.

\section{The Development of Madrasas}

Together with the enlargement of the Ottoman Empire, madrasas were built in cities other than Istanbul such as Edirne, and Bursa and many others. The madrasa called the madrasa of the Sultan built in the city of Bursa during the era of the Sultan Mohammad the Conqueror and the madrasas called Darü'l Hadis (a sort of religious school) and the Madrasa with Three Minaret Balconies built during the era of Murat II in the city of Edirne were very famous during those times. And the 
Fatih (Mohammed the Conqueror) Madrasa maintained its importance during that time. In the sixteenth century the culture of Madrasas reached its peak together with the establishment of the Madrasa of Süleymaniye which was built during the time of Suleiman the Magnificent. The first education in the Ottoman times started in the Sibyan Mektebi (Today's Elementary School) which has such various titles as mahalle mektebi (district elementary school), taş mekteb (ordinary elementary school), darü'l talim (school), darü'l ilim (school of science), and muallimhane (school for teachers). These are the continuation of the schools of the classical Islamic Civilization which were called Küttab. With the orientation and direction of the Mudarrises (professors) those who were graduated from these schools would go to other scientific centers (in Cairo, Samarqand, Bukhara, Baghdad, and Damascus), and continue with the ir education in these cities by learning the Islamic religion, Islamic culture and civilization, and then they would return to the ir home town as scientists (Genç \& Cansız, 2007; Gül, 1977). The school called Enderun (a special school in the Ottoman Palace) is an educational institute in the classical Ottoman era which is atleast as important as the Madrasa. Enderun was a unique school and it resembled Madrasas in terms of its structure. It was an educational institute which provided teaching within the palace and in which statesmen were brought up. During this time education in the Islamic monasteries was also continuing. While they were providing education for their own members at the beginning, they later on started giving education to the public.

\section{A Look at the History of Madrasas}

The concept of madrasas which was seen in the Ottoman Empire starting from the tenth century drifted apart over time from the philosophical thought at the beginning, and became institutions which reinitiated the Sunni Islamic opinion and legal understanding (Tekeli \& İlkin, 1999). The ir leading the positive sciences in the Islamic countries as institutions of education aside from the mosques is seen in the ninth and eleventh centuries. At the same time, in their development, the conflicts of madhhabs in the Religion of Islam had a great impact. The extensiveness and generality of madrasas in the Ottoman Empire which first started in İznik gained a status as a result of the establishment of the madrasa of Sultaniye in Bursa by the Sultan called Çelebi Mehmet. As an example of specialization we see the madrasa called Darüşşsafaka medicine madrasa and hospital which was the first medical school and was established in Bursa in the late fourteenth century by the Sultan called Y 1ldrim Beyazid. And also Sultan Murad II established the Saatli Madrasa and Darül-hadis (religious school) in Edirne as a result of which he started a new status era for madrasas. The levels in the madrasas were associated with the daily wage of the mudarisses (professors). For example, while the daily wages of the mudarisses in the İznik and Sultaniye madrasas were fifty mites, the daily 
wages of the mudarrisses in the madrasa with Three Minaret Balconies were one hundred mites. And this phenomenon is a sign of status differentiation and level formation in the madrasas. The first leveling determination at the scientific scale started during the era of the Sultan Mohammad the Conqueror. Because there were hardly any scientific events in Istanbul, which had been conquered Ali Kuşçu was brought for the first time from Samarkand and he was paid at first a daily wage of two hundred mites. Ali Kuşçu was a scientist who was given education and brought up by Kadizade of Bursa in Samarqand during the reign of Uluğ Bey. The biggest madrasa complex was established by Mohammed the Conqueror, the name of which was called the Islamic-ottoman social complex of Mohammad the Conqueror. In this social complex were a mosque, Tetimme Madrasas, Semaniye Madrasa and Library, a hospital, a Turkish bath, and a hospice. In this huge social complex the mosque, each madrasa, and Sahn'1 Seman has a library of its own. Sahn'1 Seman is the Court of the Eight Madrasas attached to the great mosque of Mohammad the Conqueror. Mohammad the Conqueror gave great importance to the positive and logical sciences, and because he had a rich library of his own, he sent some books to other libraries, as well. The Islamic-ottoman social complex of Mohammad the Conqueror obviously has a difference of leveling among other madrasas. Therefore the madrasas were divided into two types; one including and one excluding. Those excluding madrasas aimed at teaching Arabic at such a level that one can speak the language and read the scientific books written in Arabic and at the same time they aim at giving fundamental knowledge. Those including madrasas aimed at teaching scientific knowledge at high levels. Each of these madrasas were classified among themselves. During the era of Mohammad the Conqueror, a madrasa system of seven levels were established four of which were excluding and three of which were including (Tekeli\&İlkin, 1999; Kaz1c1, 2004). In the sixteenth century, this leveling was increased up due to the fact that Suleiman the Magnificent established the Madrasas of Suleimaniye, and as a result of this their number reached ten. And now in the madrasas and in the Islamic-Ottoman social complex of Suleimaniye some specialization schools in the fields of medical sciences on ophthalmology, mathematics and natural sciences, and Darü'l Hadis (Religious School) were giving education. The chief physician of Şifahane (Lunatic Asylum=Hospital) was paid a daily wage of thirty mites, and the mudarris (professor) of the medical school was paid a daily wage of twenty mites. The first physician that was appointed and called İsaoğlu Ahmet Çelebi was paid a daily wage of sixty mites. The madrasas and social complexes (külliye) which became widespread within the borders of the Ottoman Empire were now discriminated as the madrasas in the center and madrasas in the provinces. 


\section{The Madrasas in the Provinces}

The madrasas outside Istanbul were called the madrasas of the provinces during the Reform (Islahat) Period. In other words, because the madrasas in Anatolia were considered to be the madrasas in the provinces the Reform Regulations of the Shaykh al-Islam M. Hayri Effendi involves the central madrasas (those in Istanbul). Later, the Shaykh al-Is lam Musa Kazım Effendi unified all of the madrasas with the regulations that he issued under the title of Darü'l-Hilafeti-1Aliyye. With these regulations, the madrasas in the provinces were evaluated in the same administration and gradation, and with the same years of education. These regulations included three gradations (deracat-i selase) which were called (1) İptidai Hariç (Preliminary Exclusion), (2) İptidai Dahil (Preliminary Inclusion), and (3) Sahn (The madrasas in the court of the mosque of Mohammad the Conqueror). Accordingly, the period of education in the madrasas in the provinces was five years, and there aimed at giving a religious education at medium level (Atay,1989). The lessons in the madrasas would start after the breakfast, and continue until the noon time (till Midday Prayer). And the students would study their lessons in nthe library or in the mosque in the afternoon. During the reign of Mohammad the Conqueror, the education in the madrasas was four days a week, and four hours a day. And later during the reigns of Suleiman the Magnificent and Sultan Selim the Stern it became compulsory to take courses five hours a day (in the madrasa of Selimiye). According to the holly Koran (1969), in every madrasa there is at least one mudarris (professor). The muids are the assistants to the mudarrises (professors) who are chosen among the senior students. The muids came out together with the first establishment of the madrasas (El-Helüy, 1963; Kuran, 1969; Gül, 1997; Kazıc1, 2004).

\section{Wars and the Situation of the Madrasas}

After 1918, the Ottomans did not have any strength left to deal with the madrasas. And the nation believed that the Ottoman Empire came to an end. The periodical called Sebilür-reşad which was published in 1908 supported the Turkish War of Independence which was started in Anatolia. The madrasas were totally ignored because of the world war. The war of and struggle for independence directed the people to national goals (Atay,1989; Kazic1, 2004). And the mudarrises (professors), scientists, and muftis who were considered to be the intellectual people of those days requested the Grand National Assembly to rejuvenate the madrasas. However, the madrasas were used as lodges or headquarters during the years of war for the refugees, migrants, and soldiers. Those madrasas for which no car had been taken for centuries either demolished or became useless. Because the madrasas were deprived of financial support and because there arose a need for 
them the new regulations prepared by Hayri Effendi and Musa Effendi aimed at rejuvenation of the madrasas which was adopted by the people.

\section{The Reasons for Retrogression of the Madrasas}

Starting from the establishment of the madrasas and until the establishment of the Sahn-1 Seman madrasas (Sahn-1 Seman is the name of the court of the eight madrasas attached to the great mosque of Mohammad the Conqueror in Istanbul) during the reign of Mohammad the Conqueror hardly any problems were seen in the field of education. However, towards the end of the sixteenth century, problems were gradually seen in the education. And these problems which couldn't be solved during the improvement endeavors caused the system to fall down in the end. Due to the degrees and gradations given to the class of scientists (İlmiye) which developed in the European Side of the Empire, in Anatolia, and in Egypt lateral transfers became possible. This system which was unique in the Ottoman Empire did not make any contribution to the development of the scientists in their branch of science. On the contrary, it caused especially those mathematic ians and theology to drift away from their subjects. Because the scientists were contented with hand books at lower levels instead of scientific books scientific developments were hindered and impeded. As a result of this, quality in science had lowered down. The factors that caused the loss of functionality of the Ottoman madrasas over time can be listed as follows:

\section{The Density of the Population}

The speed of increase of the population of the Empire due to the conquering of new countries had started decreasing from the last quarter of the sixteenth century onward. The people living in the territories that were lost started retreating towards the inlands and towards the center, and as a result of this, the society turned into a society of migrating tribes without homes. The fact that some of them wanted to make use of the education system which was free at the time caused density of population in the small size madrasas because of feeding them in hospices and meeting their lodging and accommodation needs in the madrasas and Islamic monasteries. On the other hand we see the problem of employment of those who graduated from these madrasas. For this reason, in order to prevent the accumulation of students in the madrasas, a way of graduating them in a short time was preferred. This low standard and short time education caused the organized quality of education to be lost. Also the budget for the education was lowered down over time. And the functionality of the madrasas gradually decreased. 


\section{Retrogression in the Other State Organs and Bodies}

Due to the fact that the Ottoman Empire had a centralized administration structure, the conquering of new lands and new countries made it difficult for the empire to exert control over the whole empire lands. At the same time, because of the instability which arose out of the administration weaknesses within the conquered lands within the boundaries of the empire, some events such as banditry, outrage, and other illegal acts which caused harm in the legal system were taking place repeatedly.

\section{The Emergence of the Ule mazadegan Class (a sort of class of the children of scientis ts)}

In order to increase the attractiveness for the class of scientists, a salary increase was made for the children of these scientists according to the number of children that they had. The goal of this increase was to encourage the scientists for dealing with only the ir branch of science without having financial difficulties. This system was abused, and additional increases were made for each scientist without considering their eligibility. And this, as a result, caused a decrease in the quality of madrasas, which is one of the reasons for the decline of the madrasas in the Ottoman Empire.

\section{The Breach of the Laws for the Ulema Class (Scientists Class)}

The laws related to the class of scientists were made useless. The illiterate people opposed to the scientists. The mudarrises (professors) started dealing with other jobs by leaving aside their own jobs in the madrasas (not attending the madrasas, dealing with trade, giving their ratification in return for money, etc.). All these facts caused the complete retrogression of the Ulema class (class of scientists) as a result of which they lost thei,r jobs in the madrasas (Kazıc1, 2004).

\section{Retrogression of Education and Methods}

Positive sciences were discarded from the curriculum, and education was heavily concentrated on religious subjects. Such learning methods as scientific thought, discussion, and creativeness were left aside, and all the written knowledge was accepted without making any discussions as to their correctness.

\section{Indiscipline}

The students and teachers no longer took science seriously. Many people who have no relation to madrasas and to being a student started using the madrasas as their lodges. Because the mudarisses (professors) who do not do their own real jobs 
started not attending the madrasas the madrasa buildings were left unattended. And this phenomenon of loose and unattended madrasas ended up in indiscipline.

\section{Appointments}

Despite the fact that the graduates of the madrasas were subject to a period of waiting before they were appointed as mudarises, the application of apprenticeship was eliminated, and the children of the statesmen and mudarises were appointed as mudarises. As a result of this application, young children were appointed as mudarises. When we came to the years 1919-20, we see that the situation of madrasas were even worse. The factors affectiong the role and structure of the madrasas-were

1.Number of Students: The number of students accepted by some madrasas are very few. For example, four students were graduated from the department of Preachers, and two students were graduated from then department of Public Speaker and İmam (Prayer Leader). Demand for madrasas decreased and the madrasas lost their attractiveness.

2.The Situation of the Mudarises: Some madrasas were opened in order to employ the unemployed mudarises. Some mudarises that were appointed remained out of the staff. And some of the mudarises in whose positions they were appointed resigned from the madrasa. Therefore, madrasas became institutions which served show off instead of addressing needs.

3.The Situation of the Madrasas: While one madrasa was opended, another madrasa was closed. And this caused instability. And so, it was not attractive for a student to attend a madrasa where he can see no future for himself.

4.The Effect of the War: It was difficult to find students in the years of war.

5.Decrease in Population; Some madrasas were closed as a result of loss of population, and poverty and migration of the young people from Anatolia to Istanbul caused the madrasas to close down.

6.Military Service: Those young people holding a weapon joined the army, and very young people continued with their work in their villages.

7.Interest: Interest in madrasas decreased, because the publications against the madrasas had an influence. 
8.Lack of Confidence: Because the whole empire was collapsing, none of its institutions were reliable. Therefore confidence in madrasas, which were religious institutions was also lost.

9.Nationalization: Because the central madrasas were taken from the public and owned by the state with the influence of the central system, they collapsed because the state had collapsed (Atay, 1989). At the beginning, madrasas accepted students by way of examinations, and the curriculum became richer and richer, and they were criticized according to the standards of the mudarrises (professors) who were only dealing with religion and science. And now they have completely lost the ir functions, and were behind the times. And they had a primitive structure, because they couldn't keep pace with modernity and were closed to novelties. And madrasas were now unable to cope with the changing society and the modern science. They were also unable to generate knowledge and were far from being able to use contemporary knowledge. This phenomenon necessitated the opening of new military and technical schools. The renovation awareness became necessary for the whole Islamic world.

\section{References and notes:}

Ahunbay, Z., (1988). Mimar Sinan'ın Eğitim Yapıları: Medreseler, Darülkurralar, Mektepler.

Ankara:TTK Library. Regis tration No: 16410. Place no: BI/160.

Atay, H. (1983). Osman lılarda Yüksek Din Eğitimi. Medrese Proğramları:

İcazetnameler, Is lahat Hareketleri. İst: Dergah Publications: 99.

El-Helüy, A. (1963). Medreselerde Öğretim Konuları ve Metotları ve Eğ itim Hareketleri.

Translated by: Süley man Ateş. Is sue:107-108. Volu me:9. pp:30-32.

Genç, R. ve İ. Cansız. (2007). Türk Tarihi ve Uygarlığı. İstanbul: Lisans Yay ınevi.

Gül, A. (1997). Osman lı Medreselerinde Eğ itim-Öğ retim ve Bunlar Arasında Daru'l

Hadislerin Yeri. Ankara: Türk Tarih Kurumu Basımevi.

(Turkish History Institution Publication House).

Kazıc 1, Z. (2004). Os manlı'da Eğ itim Öğretim. İstanbul: Bilge Publishing House.

Kazıc1, Z. (2003). Os manlı'da Toplum Yap 1sı. İstanbul: Bilge Publishing House.

Kazıc1, Z. (2003). Os manlı'da Vakıf Medeniyeti. İstanbul: Bilge Publishing House.

Kuran, A. (1969).Anadolu Medreseleri. I.Cilt.Ankara:TTK Publishing House.

Publication No:9.

Tekeli, İ. \& S. İlkin. (1999). Os manlı İmparatorluğu'nda Eğitim ve Bilgi Üretim Sistemin in

Oluşumu ve Dönüşümü. Ankara: Türk Tarih Kurumu Basımevi

(Turkish History Institution Publication House). 


\title{
Summary \\ Functions of 'Madrasas' in the Ottoman Period
}

\author{
Ayla Akbas h \\ Kocaeli University,Turkey
}

In this study certain educational institutions such as madrassahs, kulliyes and mosques that contributed to environment in terms of education in the Ottoman period (middle of the fifteenth century-beginning of the nineteenth century)are researched with regards to educational system, curriculum, mudarrises, students and training. The functions and effects of the madrassahs at that time as well as their reflection in our time are dealt with. In this context, some educational institutions included by certain Anatolian madrassahs such as darulkurra, darulhadith, sahniseman and schools, which are currently existed and not, have been taken in examination. Incorporating madrassahs, which are public instutions in the Ottoman period, in the state organis ation has been started with the Fatih madrassahs that were established by Fatih (Sultan Mehmed the Conqueror) and structuring of madrassah order was quickened after the conquest. In time, the cities such as İstanbul (capital city), Edirne, Bursa, İznik, Trabzon, Konya and Diyarbakır have had the most madrassahs. The large majority of madrassahs of Sinan the Architect have been built in Anatolia and in other cities of the Empire. The first Ottoman madrassah was established in İznik and has become widespread in time. In consequence of being institutions in which training was giving according to the curriculum and ratification of mudarris and having distinctive architectural characteristics in their cubicles, porches, classes, iwans and şadırvans gave rise to them having a respectable position in the society. It is commented that the madrassahs that are the symbol of classical Otto man arcitecture have been retrograded later on. In the scope of madrassahs located in the Antalya region the importance and contribution of them, which have been improved as the reflection of the social changes and have been opened to changes with their internal/external dynamics, and their capability of being met the requirements of society have been examined and explained descriptively together with their contributions to educational mantality in our time.

Key words: Ottoman period, educational institutions, madrassah, kulliyes, mosques 